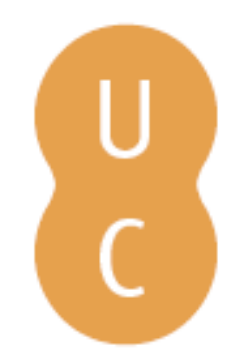

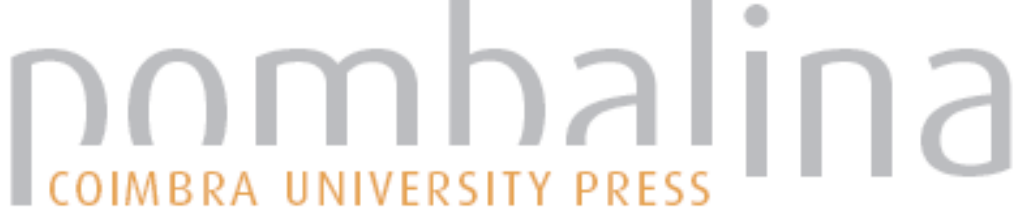

\section{Mapping Canadian Interface Areas}

Autor(es): Johnston, Lynn; Flannigan, Mike

Publicado por: Imprensa da Universidade de Coimbra

URL

persistente: URI:http://hdl.handle.net/10316.2/44692

DOI: $\quad$ DOI:https://doi.org/10.14195/978-989-26-16-506_175

Accessed : $\quad$ 26-Apr-2023 11:57:55

A navegação consulta e descarregamento dos títulos inseridos nas Bibliotecas Digitais UC Digitalis, UC Pombalina e UC Impactum, pressupõem a aceitação plena e sem reservas dos Termos e Condições de Uso destas Bibliotecas Digitais, disponíveis em https://digitalis.uc.pt/pt-pt/termos.

Conforme exposto nos referidos Termos e Condições de Uso, o descarregamento de títulos de acesso restrito requer uma licença válida de autorização devendo o utilizador aceder ao(s) documento(s) a partir de um endereço de IP da instituição detentora da supramencionada licença.

Ao utilizador é apenas permitido o descarregamento para uso pessoal, pelo que o emprego do(s) título(s) descarregado(s) para outro fim, designadamente comercial, carece de autorização do respetivo autor ou editor da obra.

Na medida em que todas as obras da UC Digitalis se encontram protegidas pelo Código do Direito de Autor e Direitos Conexos e demais legislação aplicável, toda a cópia, parcial ou total, deste documento, nos casos em que é legalmente admitida, deverá conter ou fazer-se acompanhar por este aviso.

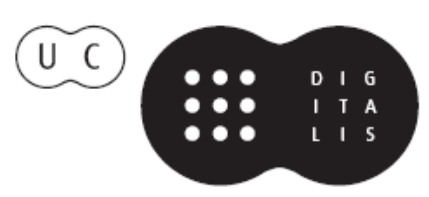




\section{ADVANCES IN}

\section{FOREST FIRE RESEARCH}

\section{8}

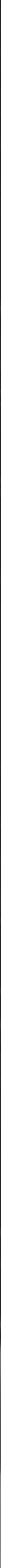


Short contribution - Fire at the Wildland Urban Interface

\title{
Mapping Canadian Interface Areas
}

\author{
Lynn Johnston $^{1 *}$; Mike Flannigan ${ }^{2}$ \\ ${ }^{I}$ Canadian Forest Service. 1219 Queen Street E., Sault Ste Marie, Ontario, Canada, P6A 2E6, \\ \{lynn.johnston@canada.ca*\} \\ ${ }^{2}$ University of Alberta. 7-13A General Services, University of Alberta, Edmonton, Alberta, Canada, T6G \\ 2H1, \{mike.flannigan@ualberta.ca\}
}

\begin{abstract}
Abstrac t
This project aimed to produce the first map of the Canadian wildland-urban interface (WUI). We also extended the interface concept beyond the traditional "urban" structures of the wildland-urban interface to include industrial structures (e.g. oil and gas structures) or infrastructure values (e.g. roads, powerlines, railways); producing two additional national maps to reflect the interface areas of these potentially vulnerable industrial structures (i.e. the wildland-industrial interface) or infrastructure values (i.e. the wildland-infrastructure interface) with wildland fuels. The interface maps provide a baseline for future work but also have a variety of practical applications such as fire management planning and decision support, insurance, municipal planning, and fire mitigation.
\end{abstract}

Keywords: wildland-urban interface, wildland fire, fire risk, GIS

\section{Introduction}

Recent Canadian wildfire disasters such as Slave Lake (2011) and Fort McMurray (2016) are examples of the destructive power of wildfires to human structures. Fires that have the potential to cause this kind of destruction are referred to as "interface" fires (Figure 1).

The wildland-urban interface (WUI) is where homes or other human structures meet with or intermingle amongst burnable wildland fuels. Canadian fire management agencies actively mitigate and suppress fire in these interface areas in order to protect human life and structural values.

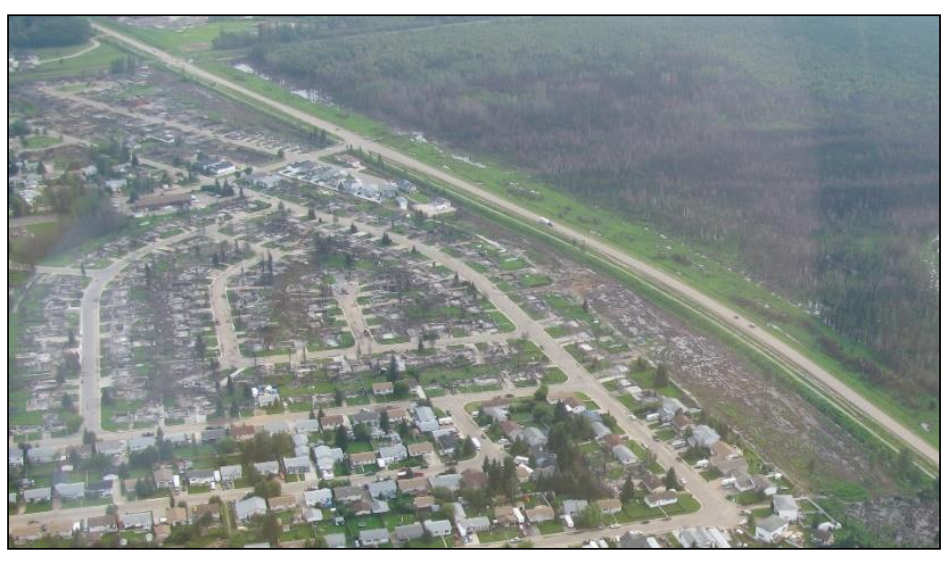

Figure 1 - Destruction of homes in Slave Lake, Alberta, Canada in 2011 due to an interface fire (photo credit: Mike Flannigan/University of Alberta).

For effective fire management in the interface, we need information on what areas are at risk.

In Canada, a national examination of risk was not available and represented a large gap in wildfire research. The WUI has been mapped and studied in other areas of the world, with many studies additionally quantifying interface fire risk (e.g. Radeloff et al. 2005; Theobald and Romme 2007; Vadrevu et al. 2010; Haas et al. 2013; Chuvieco et al. 2014; Thomas and Butry 2014; Fox et al. 2015; Radeloff et al. 2018). However, in Canada there is very limited information on this topic despite the potential for destructive impacts of wildfire on human structures.

The objective of this project is to map the interface areas of Canada that are at risk to wildland fires. There are two main components to this project: 1) mapping interface areas and 2) quantitatively assessing the amount of fire risk in those interface areas.

Part one of this project is complete (Johnston and Flannigan 2018); it resulted in the production of 
the first national map of the interface in Canada. This map includes the more traditional interface of wildland fuels with homes, commercial buildings, and public structures, forming the wildland-urban interface (WUI). We also extended the interface concept to industrial (e.g. oil and gas or mining structures) and infrastructure (e.g. roads, railways, powerlines) areas to provide a more comprehensive view of potential impacts to buildings and essential infrastructure.

\section{Methods}

There are a wide variety of ways of defining and mapping interface areas (see Mell et al. 2010; Platt 2010). This study selected a fuels-focused definition of the interface areas, using a buffer around each potentially vulnerable feature. A brief summary of the methods used to map the interface will be covered here, but for full methods see Johnston and Flannigan (2018).

Mapping the interface areas required data on both structures/infrastructure and on wildland fuels (Fig. 2a). Structure/infrastructure locations were taken from the CanVec+ (Natural Resources Canada 2015a) dataset, and each potentially vulnerable feature was included in calculations of the wildlandurban interface, wildland-industrial interface, or infrastructure interface, depending on if they were primarily urban/community features, industrial features, or infrastructure.

Relevant fuels data was extracted from the Land Cover circa 2000 (Natural Resources Canada 2015 b) dataset. The fuels were then classified according to their relative fire hazard they may impart to structures (similar to the methods of Theobald and Romme (2007)). A "high hazard" fuel would be something like a continuous conifer forest, which can have potentially extreme fire behaviour and could impart extreme fire risk to nearby structures. A "low hazard" fuel would be something like a sparsely vegetated shrubland, which has low potential for fire spread and would impart a much lower risk to nearby structures.

To produce the actual interface areas, a buffer of vegetated areas was calculated around each potentially vulnerable structure. The size and shape of the buffer was dictated by the type and arrangement of surrounding fuels. A large buffer (and therefore a large interface area) would be produced with higher hazard fuels, and smaller buffers (small interface areas) where there is less fuel or lower hazard fuels. The maximum distance the buffer could extend was limited to $2400 \mathrm{~m}$. Nonfuel areas were removed from the buffered areas, resulting in the final interface areas (Fig. 2b).

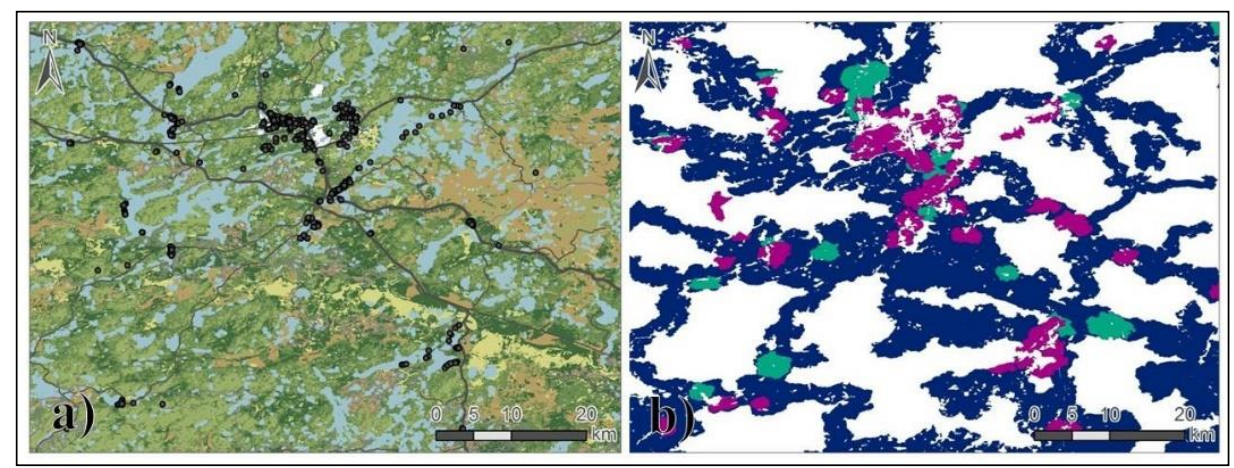

Figure 2 - Example maps showing a) the data inputs: the fuels (greens, browns) and values (black), and also water is shown in blue, and then image b) shows the wildland-urban interface (magenta), wildland-industrial interface (cyan), and infrastructure interface (navy).

\section{Results}

Nationally, these interface maps (Figure 3) show that Canada has 32.3 million ha of WUI (3.8\% of total national land area), 10.5 million ha of wildland-industrial interface (1.2\%), and 109.8 million ha of infrastructure interface $(13.0 \%)$. This is a widespread issue affecting large areas of Canada. 


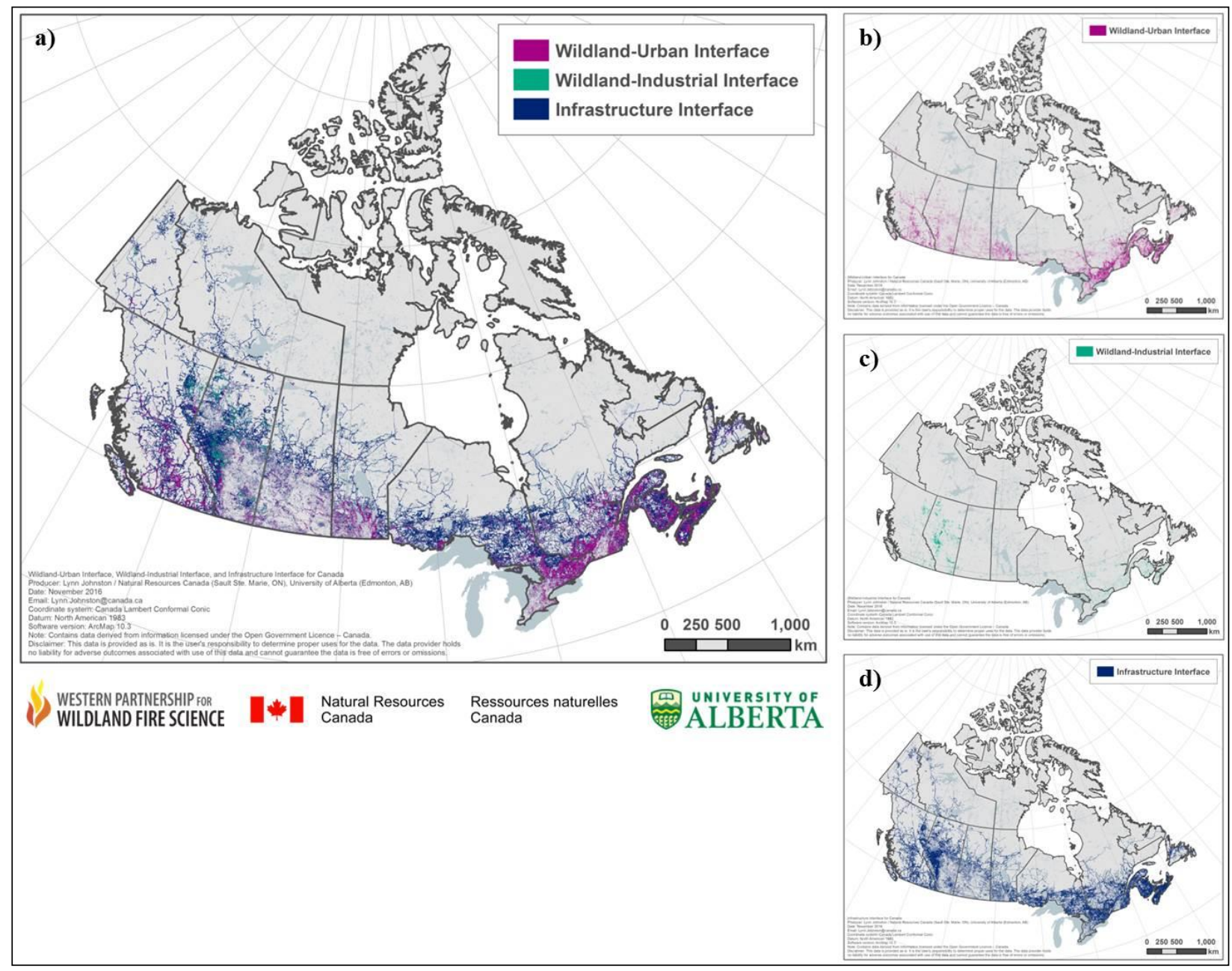

Figure 3 - Canadian national interface maps, with a) showing all three interface "types" together, b) showing the wildland-urban interface (WUI), c) showing the wildland-industrial interface (WII), and d) showing the infrastructure interface.

Overall, $60 \%$ of all cities, towns, settlements, and reservations across Canada were found to have a significant amount of WUI (defined as those with more than 500 ha of WUI within a $5 \mathrm{~km}$ radius). There have been many recent fires near or within the interface areas; $40 \%$ of recent fires would be considered an "interface fire". For more information on the production and initial analysis of these maps, see Johnston and Flannigan (2018).

\section{Discussion}

Maps of the interface may imply that there is a fire risk, but a map of the interface alone is not a proxy for risk. Mapping the interface is the first step in assessing interface fire risk and provides the locations of where fire risk to interface areas may be possible (i.e. where wildland fuels and human structures intermix or meet). A multitude of additional factors need to be considered to fully quantify risk. Fire risk is inconsistently defined in wildfire literature, but the traditional natural hazards risk definition assesses fire risk as the conditional probability of an event occurring multiplied by the expected consequence when the event occurs (Finney 2005; Hardy 2005; Thompson et al. 2011; Haas et al. 2013; Miller and Ager 2013; Chuvieco et al. 2014). We can further refine the definition of fire risk to the function of likelihood, intensity, and effects (e.g. Thompson and Calkin 2011; Miller and Ager 2013). Assessment of these three risk components can use variety of potential approaches and 
quickly develops into a complex paradigm with many elements, as visualized in the word cloud in Figure 4.

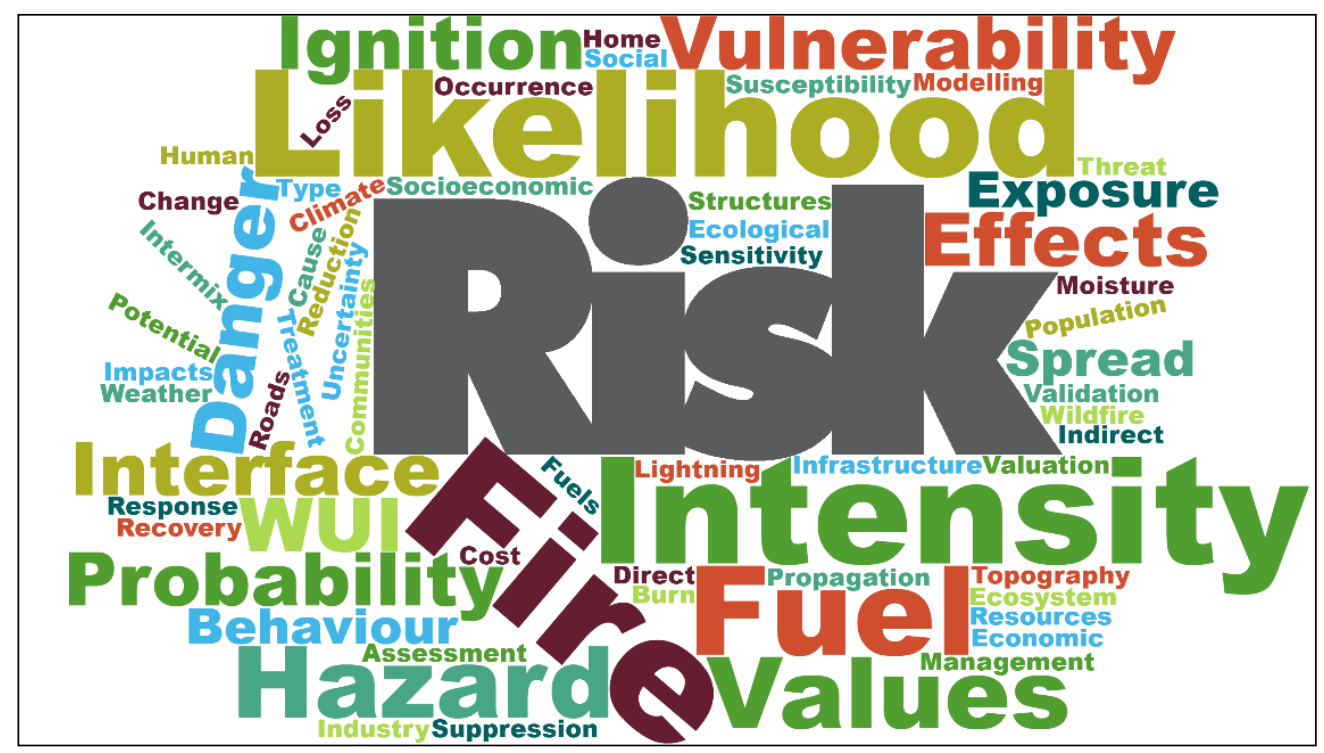

Figure 4 - Word cloud of terms related to fire risk.

The results of this project will be used for the second component of this project, i.e. quantifying fire risk within interface areas. In addition, we will investigate fire activity within these interface areas to characterize fire intensity, seasonality, and ignition sources. Additionally, these maps will be used to detect recent growth patterns in the interface and to model future interface areas.

The interface maps are available for practical applications, and if used for the correct application and at the correct spatial scale, can be useful for a variety of applications, for example: fire insurance, municipal planning, fire suppression, values protection, fuel management, and forestry.

\section{References}

Chuvieco, E, Aguado, I, Jurdao, S, Pettinari, ML, Yebra, M, Salas, J, Hantson, S, de la Riva, J, Ibarra, P, Rodrigues, M, Echeverria, M, Azqueta, D, Roman, MV, Bastarrika, A, Martinez, S, Recondo, C, Zapico, E, Martinez-Vega, FJ (2014) Integrating geospatial information into fire risk assessment. International Journal of Wildland Fire 23, 606-609. 10.1071/WF12052.

Finney, MA (2005) The challenge of quantitative risk analysis for wildland fire. Forest Ecology and Management 211, 97-108. 10.1016/j.foreco.2005.02.010.

Fox, D, Martin, N, Carrega, P, Andrieu, J, Adnès, C, Emsellem, K, Ganga, O, Moebius, F, Tortorollo, N, Fox, E (2015) Increases in fire risk due to warmer summer temperatures and wildland urban interface changes do not necessarily lead to more fires. Applied Geography 56, 1-12. 10.1016/j.apgeog.2014.10.001.

Haas, JR, Calkin, DE, Thompson, MP (2013) A national approach for integrating wildfire simulation modeling into Wildland Urban Interface risk assessments within the United States. Landscape and Urban Planning 119, 44-53. 10.1016/j.landurbplan.2013.06.011.

Hardy, CC (2005) Wildland fire hazard and risk: problems, definitions, and context. Forest Ecology and Management 211, 73-82. 10.1016/j.foreco.2005.01.029.

Johnston, LM, Flannigan, MD (2018) Mapping Canadian wildland fire interface areas. International Journal of Wildland Fire 27, 1-14. 10.1071/WF16221. 
Mell, WE, Manzello, SL, Maranghides, A, Butry, D, Rehm, RG (2010) The wildland-urban interface fire problem - current approaches and research needs. International Journal of Wildland Fire 19, 238-251. 10.1071/WF07131.

Miller, C, Ager, AA (2013) A review of recent advances in risk analysis for wildfire management. International Journal of Wildland Fire 22, 1-14.

Natural Resources Canada (2015a) CanVect. Dataset. Used under the Open Government Licence Canada. (EaSS GeoGratis Client Services. Natural Resources Canada, Canada Centre for Mapping and Earth Observation). ftp://ftp2.cits.rncan.gc.ca/pub/canvec/archive/canvec+_archive_20151029/doc/CanVec+_en_relea se_notes.pdf.

Natural Resources Canada (2015b) Land Cover, circa 2000 - vector. Dataset. Used under the Open Government Licence - Canada. (EaSS GeoGratis Client Services. Natural Resources Canada, Canada Centre for Mapping and Earth Observation). www.GeoGratis.gc.ca.

Platt, RV (2010) The Wildland-Urban Interface: Evaluating the Definition Effect. Journal of Forestry 108, 9-15.

Radeloff, VC, Hammer, RB, Stewart, SI, Fried, JS, Holcomb, SS, McKeefry, JF (2005) The wildlandurban interface in the United States. Ecological Applications 15, 799-805.

Radeloff, VC, Helmers, DP, Kramer, HA, Mockrin, MH, Alexandre, PM, Bar-Massada, A, Butsic, V, Hawbaker, TJ, Martinuzzi, S, Syphard, AD (2018) Rapid growth of the US wildland-urban interface raises wildfire risk. Proceedings of the National Academy of Sciences 115, 3314-3319. 10.1073/pnas.1718850115.

Theobald, DM, Romme, WH (2007) Expansion of the US wildland-urban interface. Landscape and Urban Planning 83, 340-354. 10.1016/j.landurbplan.2007.06.002.

Thomas, DS, Butry, DT (2014) Areas of the US wildland-urban interface threatened by wildfire during the 2001-2010 decade. Natural Hazards 71, 1561-1585. 10.1007/s11069-013-0965-7.

Thompson, MP, Calkin, DE (2011) Uncertainty and risk in wildland fire management: a review. Journal of Environmental Management 92, 1895-1909.

Thompson, MP, Calkin, DE, Finney, MA, Ager, AA, Gilbertson-Day, JW (2011) Integrated nationalscale assessment of wildfire risk to human and ecological values. Stochastic Environmental Research and Risk Assessment 25, 761-780. 10.1007/s00477-011-0461-0.

Vadrevu, KP, Eaturu, A, Badarinath, K (2010) Fire risk evaluation using multicriteria analysis - a case study. Environmental monitoring and assessment 166, 223-239. 